Pesq. Vet. Bras. 28(4):207-215, abril 2008

\title{
Immunohistochemical evaluation of e-cadherin, Ki-67 and PCNA in canine mammary neoplasias: Correlation of prognostic factors and clinical outcome ${ }^{1}$
}

\author{
Debora A.P.C. Zuccari2*, Marcilia V. Pavam³ , Ana Carolina B. Terzian ${ }^{4}$, \\ Rodrigo S. Pereira ${ }^{5}$, Camila M. Ruiz ${ }^{6}$ and Joanna Coelho Andrade ${ }^{\dagger}$
}

\begin{abstract}
Zuccari D.A.P.C., Pavam M.V., Terzian A.C.B., Pereira R.S., Ruiz C.M. \& Andrade J.C. ${ }^{\dagger}$ 2008. Immunohistochemical evaluation of $\mathrm{Ki}-67$ and PCNA in canine mammary neoplasias: Correlation with prognostic factors and clinical outcome. Pesquisa Veterinária Brasileira 28(4):207-215. Centro Regional de Bioterismo, FAMERP, Av. Brigadeiro Faria Lima 5416, São José do Rio Preto, SP 15090-000, Brazil. E-mail: debora.zuccari@famerp.br

E-cadherin is a cell-cell adhesion molecule and low e-cadherin expression is related to invasiveness and may indicate a bad prognosis in mammary neoplasms. The expression of cell proliferation markers PCNA and especially Ki-67, has also proved to have a strong prognostic value in this tumor class. The expression of these markers was related to the clinical-pathological characteristics of 73 surgically removed mammary tumors in female dogs by immunohistochemistry. There was no statistical correlation between these markers and death by neoplasm, survival time and disease-free interval. However, the loss of e-cadherin expression and marked Ki-67 expression $(p=0.016)$ were considered statistically significant for the diagnosis $(p=0.032)$. When evaluated as independent factors, there was evidence of the relationship between the loss of e-cadherin expression and high PCNA expression with changes in the body status (divided into obese, normal and cachectic) of female dogs ( $p=0.030)$; there was also evidence of the relationship between pseudopregnancy and e-cadherin alone $(\mathrm{p}=0.021)$ and for ulceration and PCNA alone $(p=0.035)$. The significant correlation between the markers expression and these well known prognostic factors used individually or in combination suggests their prognostic value in canine mammary tumors.
\end{abstract}

INDEX TERMS: Canine, cell proliferation marker, e-cadherin, immunohistochemistry, mammary neoplasm.

${ }^{1}$ Received on November 10, 2007.

Accepted for publication on March 31, 2008.

${ }^{2}$ Centro Regional de Bioterismo, Faculdade de Medicina de São José do Rio Preto (Famerp), Av. Juscelino K. Oliveira 1220, Rua 07, Casa 140, São José do Rio Preto, SP 15091-450, Brazil. *Autor para correspondência: debora.zuccari@famerp.br

${ }^{3}$ Médica Veterinária autônoma, Famerp, Av. Brigadeiro Faria Lima 5416, Vila São Pedro, São José do Rio Preto, SP 15090-000.

${ }^{4}$ Instituto de Biociências, Letras e Ciências Exatas (Ibilce), UnespSão José do Rio Preto, Rua Cristóvão Colombo 2265, Bairro Jardim Nazareth, São José do Rio Preto, SP 15054-000.

${ }^{5}$ Centro Universitário de Rio Preto, BR $153 \mathrm{Km}$ 69, São José do Rio Preto, SP 15100-000.

6 VETPAT-Laboratório de Patologia e Biologia Molecular Veterinária, Rua Coronel Manuel Moraes 146, Campinas, SP 13073-022, Brazil.

† Graduanda em Medicina Veterinária (In memoriam).
RESUMO.- [Avaliação imuno-histoquímica da e-caderina, Ki-67 e PCNA nas neoplasias mamárias caninas: correlação dos fatores prognósticos com a evolução clínica.] A e-caderina é uma molécula de adesão celular e a perda de sua expressão esta relacionada à invasão tumoral podendo indicar um prognóstico ruim nas neoplasias mamárias. A expressão dos marcadores de proliferação celular PCNA e especialmente o Ki-67, também têm mostrado forte valor prognóstico nesta classe tumoral. A expressão imuno-histoquímica destes marcadores foi relacionada com as características clinico-patológicas de 73 tumores removidos cirurgicamente de fêmeas caninas. Não houve correlação estatística entre estes marcadores 
e a morte por neoplasia, tempo de sobrevida e intervalo livre de doença. Entretanto, a perda da expressão da ecaderina e a forte expressão do Ki-67 ( $p=0,016)$ foram considerados estatisticamente significativos quando relacionados com o diagnóstico $(p=0,032)$. Quando avaliados os fatores independentes, houve evidência de associação entre a perda de expressão da e-caderina e a alta expressão do PCNA com as mudanças no estado nutricional das cadelas (divididas em obesas, normais e caquéticas) $(p=0,030)$; houve também evidência de associação entre a pseudociese e a expressão da e-caderina $(p=0,021)$ e com a ulceração e a expressão do PCNA $(p=0,035)$. A correlação significativa entre a expressão dos marcadores e estes, bem conhecidos fatores prognósticos usados individualmente ou em associação, sugere importante valor prognóstico destes marcadores nos tumores mamários caninos.

TERMOS DE INDEXAÇÃO: Canino, marcador de proliferação celular, e-caderina, imuno-histoquímica, neoplasma mamário.

\section{INTRODUCTION}

Mammary neoplasias are the most common tumors in female dogs, and are responsible for approximately $52 \%$ of all neoplasias in this animal population (MacEwen 1990, Sørenmo 1998, Zuccari 2001). It is known that a large number of factors are indicators of breast cancer prognosis, including the type, size and classification of the tumor in addition to the involvement of surrounding lymphoid tissue. These factors may be used individually or in combination to define the prognosis and outcome of the case (Perez et al. 2000, Van T Veer et al. 2002). Moreover, although this is a more complex procedure, the evaluation of the expression of one or more prognosis markers is a useful and conclusive tool (Thomas 2000). E-cadherin is a cellcell adhesion protein and it is extremely important in epithelial differentiation. E-cadherin expression and function has been extensively studied regarding its role in tumorigenesis and it is considered a powerful suppressor of mammary tumor invasions (Takeish 1991, Gamallo et al. 1993, Pignatelli 1993, Lipponen et al. 1994, Guriec et al. 1996, Siitonen et al. 1996, Charpin et al. 1997, Zschiesche et al. 1997, Asgeirsson et al. 2000, Heimann et al. 2000, Berx \& Roy 2001, Reis-Filho et al. 2002, Kowalsky et al. 2003, Oesterreich et al. 2003, Matos et al. 2006). The e-cadherin gene is located in region $16 q 22.1$ of the human chromosome, which is frequently affected by low heterozygosis in sporadic mammary neoplasms (Berx \& Roy 2001, Oesterreich et al. 2003). The loss or decrease of e-cadherin expression has been associated to a worse differentiation of several tumors such as the colon, pancreas bladder and breast (Pignatelli et al. 1992, Pignatelli 1993, Glukchova et al. 1995).

The relationship between E-cadherin expression and histological grade (Gamallo et al. 1993, Guriec et al. 1996, Siitonen et al. 1996, Zschiesche et al. 1996, Charpin et al. 1997), histological type (Gamallo et al. 1993, Guriec et al.
1996, Zschiesche et al. 1996, Charpin et al. 1997, Matos et al. 2006), hormonal receptors (Siitonen et al. 1996, Charpin et al. 1997, Gillett et al. 2001), presence of metastasis in lymph nodes (Zschiesche et al. 1996, Matos et al. 2006, Siitonen et al. 2006), necrosis (Matos et al. 2006), survival rate (Guriec et al. 1996, Zschiesche et al. 1997, Asgeirsson et al. 2000, Pedersen et al. 2002, Brunetti et al. 2005) and time free from metastasis (Pedersen et al. 2002, Brunetti et al. 2005), P53 and cerbB-2 expression (Charpin et al. 1997) has been reported; there was also an association between low e-cadherin expression and the type of tumor differentiation (Restucci et al. 1997, Reis et al. 2003), but there was no significant association with hormonal receptors (Guriec et al. 1996, Kovacs et al. 2003), c-erbB-2 expression (Zschiesche et al. 1997), lymph node involvement (Kovacs et al. 2003), or clinical factors such as age, menopause and tumor size (Guriec et al. 1996, Kovacs et al. 2003).

$\mathrm{KI}-67$ is a nonhistone protein, which is not expressed in $\mathrm{GO}$ cells, but it might be detected in the active phases of the cellular cycle, G1, S, G2 and mitosis (Gerdes et al. 1884 ), with a mean life of less than one hour (Bruno \& Darzynkiewicz 1992).

The proliferating cell nuclear antigen (PCNA) is an acid nuclear protein of $36 \mathrm{kDa}$ which works as a DNApolymerase delta co-factor (Bravo et al. 1987, Oyama et al. 1995). It is present in all of the phases of the cellular cycle, but its synthesis is greater in the S phase, and it is also associated to DNA replication and repair (McMormick \& Hall 1992, Sanchez \& Elledge 1995 Queiroz 1997).

The proliferation index (PI), determined by cell cyclerelated markers such as Ki-67 and proliferating cell nuclear antigen (PCNA) has prognostic value in human mammary carcinomas. Some researchers have reported the value of these nuclear antigens in the prediction of disease-free interval and overall survival as independent prognostic factors in multivariate analyses (Takeishi 1991, Wintzer et al. 1991, Veronese et al. 1993, Rabenhorst et al. 1994, Delahunt et al. 1995, Pena et al. 1998, Fitzgibbons et al. 2000). Other authors have reported inconsistent results (Thomas et al. 1993, Gasparini et al. 1994).

The goal of this study was to investigate e-cadherin and proliferation markers expression in histopathological specimens of canine neoplastic mammary tissue and to correlate the immunohistochemical results with clinical and histopathological characteristics of the tumors and patient outcome. We used an antibody developed against the antigens and effective in formalin-fixed, paraffin-embedded material.

\section{MATERIALS AND METHODS}

\section{Specimens}

Seventy-three tumor fragments were surgically removed from 2 to 17-year-old female dogs (mean 10 years) of pure breed and undefined breed. Fragments were fixed in $10 \%$ buffered formol solution. Clinical data, reproductive history and hormonal status were obtained in the initial evaluation and include feeding, 
number of pregnancies, history of pseudopregnancy, prevention of estrus, evolution time. Macroscopic characteristics of the injury were analyzed (location, size and ulceration) in addition to some microscopic characteristics such as tubular architecture, presence of mitosis, cytological and histological degree, necrosis and lymphocyte infiltration. The presence of metastasis, involvement of lymph nodes, disease-free interval (DFI) and overall survival (OS) were also evaluated.

Before removal, each tumor was clinically observed and palpated, and the following data were recorded: location in the mammary chain, dimensions, skin ulceration and cutaneous and underlying tissue fixation. Small tumors $(<1 \mathrm{~cm})$ were included in their entirety, while in larger tumors sequential segments $5 \mathrm{~mm}$ apart were cut to provide tissue blocks. After dehydration and embedment in paraffin wax, sections (3 im) were cut from each block. One section was stained with hematoxylin and eosin and selected sections, representative of the tumor type (and free of necrosis, hemorrhage and inflammatory cell infiltrates) were used for immunohistochemistry (IHC). Histopathological classification of tumor type was based on the WHO classification system (AFIP) for canine mammary tumors. Malignancy in histological specimens was based on cellular features of malignancy, vascular or lymphatic invasion, and nuclear grade. By using a previously established histological grading system for human breast carcinomas and an evaluation of cellular criteria of malignancy, 3 degrees of histological malignant grade tumors were identified in canine mammary tumors (Misdorf 2002). For DFI (disease-free survival) and OS (overall survival), we considered high when it was more than 18 months; medium, from 6 to 18 months and low for dogs that had survived less than 6 months.

\section{Immunohistochemistry}

Slides underwent peroxidase block using hydrogen peroxide (10V) and were steam-treated in citrate buffer $(\mathrm{pH} 7.0)$ to obtain antigen retrieval. Incubation with primary antibody over night at $-4^{\circ} \mathrm{C}$ with $\mathrm{E}$-cadherin antibody ( $\mathrm{NCH}-38$, Biogen): 1/50; anti- Ki67 antibody (MIB-1, Novocastra) and with anti-PCNA anti-body (PC-10, Novocastra), both diluted at 1:100. After incubation with the secondary antibody (Solution A - Dako LSAB kit +, Peroxidase-Universal), the slides were incubated with Streptoavidin/Peroxidase complex (Solution B - Dako LSAB kit Peroxidase-Universal), for 30 minutes. Staining with DAB chromogenic substrate (20mil chromogen $+1 \mathrm{~mL}$ Buffer, Dako ${ }^{\circledR}$ ) and counterstained with Harris Hematoxylin.

There was always a positive control for the tested antibody and a negative control without primary antibody. Marker expression was assessed according to the grading system proposed by ALLRED et al. (1998): - (negative), + (up to $25 \%$ of positive cells), $++(25 \%-50 \%$ of positive cells), $+++(50 \%-75 \%$ of positive cells), $++++(<75 \%$ of positive cells).

\section{Statistical analysis}

Multivariate logistic regression analyses of prognostic factors were performed. These analyses evaluate the influence of sets of variables on a dependent variable (recurrences, metastasis, disease-free survival, overall survival). Results were analyzed on the basis of tumor diagnosis and patient outcome, using histological expression of the antibodies.

\section{RESULTS}

The 73 female dogs ranged from 2 to 17 years of age (mean 10 years). Only 22\% (16) of them were fed dog chow alone and $78 \%$ (57) ate homemade food. All of them were intact female dogs, $51 \%$ (37) had had no parturition and $49 \%$ (36) had had only one parturition. Twenty-six female dogs had been prevented from estrus by the administration of estrogens/progestagens combinations. Anamnesis revealed previous pseudopregnancy in 28 female dogs. Fourteen percent (10) had benign mammary tumors. Of the malignant neoplasms, 65\% (48) were carcinomas and $21 \%$ (15) were complex carcinomas. Dogs with complete clinical history and clinical data on the tumors, which had been previously histologically diagnosed, were included in the follow-up study. Twenty eight of the 73 tumors recurred, and 10\% (7) metastasized, 7 of which also recurred. Of the animals with malignant tumor, $62 \%$ (45) were alive and 7\% (5) died or were euthanized due to neoplasm. At the end of the follow-up period, $22 \%$ (16) died and $9 \%$ (7) died from other causes. Twenty dogs had low to medium disease-free survival (DFS) and fifty-three had high DFS. The overall survival (OS) was high in fifty-seven dogs, low to medium in sixteen. No recurrence or metastases were presented in dogs with benign tumors, and OS was high for all of these dogs.

\section{Clinical data}

To determine the possible influence of different factors such as age or hormonal history on tumor, their relationship with e-cadherin, Ki-67 and PCNA, scores was investigated.

There was a significant difference among mean ages according to survival time $(p<0.05)$. Tukey's test showed that those surviving less than 6 months were older (in average) than those surviving over 18 months $(p<0.05)$ (Table 1). There was a significant association between histopathological diagnosis and histological grade $(p=0.004$, according to the analysis of dependence) and necrosis $(p=0.003)($ Table 2$)$; there was evidence of a

Table 1. Mean ages according to survival time in bitches with mammary neoplasm

\begin{tabular}{cccc}
\hline Survival time & $\begin{array}{c}\text { Number of } \\
\text { animals }\end{array}$ & Mean ages & P value $^{\mathrm{a}}$ \\
\hline$<6$ months & 13 & 10.538 & \\
$>18$ months & 54 & 8.386 & $\mathrm{p}<0.05$ \\
6-18 months & 4 & 9.750 & \\
\hline a Tukey's Test. & & &
\end{tabular}

Table 2. Histological grade and presence of necrosis according to the histopathological diagnosis of mammary neoplasms in bitches

\begin{tabular}{cccc}
\hline Histological grade & Benign & Malignant & P value $^{\mathrm{a}}$ \\
\hline Good & $36.59 \%(27)$ & $19.36 \%(14)$ & \\
Moderate & $60.98 \%(44)$ & $51.61 \%(38)$ & $\mathrm{p}=0.004$ \\
Poor & $2.44 \%(2)$ & $29.03 \%(21)$ & \\
Necrosis & & & \\
None & $75.61 \%(55)$ & $35.48 \%(26)$ & \\
Mild & $14.63 \%(11)$ & $35.48 \%(26)$ & $\mathrm{p}=0.003$ \\
Moderate + & $9.76 \%(7)$ & $29.03 \%(21)$ & \\
Intense & & &
\end{tabular}

a Analysis of Dependency. 
higher chance of metastasis with DFS up to 18 months ( $p=0.007$, according to Fisher's Test) and with OS lower or equal to 18 months ( $p=0.0023$, according to Fisher's test) (Table 3).

E-cadherin expression was located along the cytoplasmic membrane. It was + (focal) in $29 \%$ of the cases; $++(25-50 \%$ of positive cells $)$ in $26 \%$; +++ $(50-75 \%$ of

Table 3. Development of metastasis within 18 postoperative months and survival time lower or equal to 18 months

\begin{tabular}{|c|c|c|c|c|}
\hline & & No & Yes & $\mathrm{P}$ value ${ }^{\mathrm{a}}$ \\
\hline \multicolumn{5}{|c|}{ Metastasis $\mathrm{x}$ disease-free interval up to 18 months } \\
\hline \multicolumn{2}{|c|}{$<=18$ months } & $70.00 \%(51)$ & $30.00 \%(22)$ & $p=0.007$ \\
\hline \multicolumn{2}{|c|}{$>18$ months } & $98.11 \%(72)$ & $1.89 \%(1)$ & \\
\hline \multicolumn{5}{|c|}{ Metastasis $\mathrm{x}$ survival time lower or equal to 18 months } \\
\hline \multirow{2}{*}{\multicolumn{2}{|c|}{$\begin{array}{l}<=18 \text { months } \\
>18 \text { months }\end{array}$}} & $68.75 \%(50)$ & $31.25 \%(23)$ & $p=0.0023$ \\
\hline & & $96.49 \%(70)$ & $3.51 \%(3)$ & \\
\hline \multicolumn{5}{|c|}{ aFisher's Test. } \\
\hline \multicolumn{5}{|c|}{$\begin{array}{l}\text { Table 4. E-cadherin expression according to the } \\
\text { diagnosis of mammary neoplasms in bitches }\end{array}$} \\
\hline \multicolumn{2}{|r|}{ Benign } & Carcinoma & $\begin{array}{l}\text { Complex } \\
\text { carcinoma }\end{array}$ & $P$ value \\
\hline & 5.88 & 32.3 & $61.76 \%(45)$ & \\
\hline Intense & $22.22 \%(16)$ & $55.56 \%(41)$ & $22.22 \%(16)$ & $p=0.032$ \\
\hline Negative & $9.09 \%(7)$ & $45.45 \%(33)$ & $45.45 \%(33)$ & \\
\hline
\end{tabular}

Table 5. Presence of pseudocyesis according to Ecadherin expression

\begin{tabular}{ccccc}
\hline & No & Yes & Yes (recurrent) & $\mathrm{P}$ value $^{\mathrm{a}}$ \\
\hline Negative & $90.91 \%(66)$ & $9.09 \%(7)$ & - & $\mathrm{p}=0.021$ \\
Positive & $56.45 \%(41)$ & $27.42 \%(20)$ & $16.13 \%(12)$ & \\
\hline
\end{tabular}

a Fisher's Test.

Table 6. Body status changes according to E-cadherin expression

\begin{tabular}{ccccc}
\hline & Cachetic & Normal & Obese & P value $^{\mathrm{a}}$ \\
\hline Negative & $27.27 \%(20)$ & $45.45 \%(33)$ & $27.27 \%(20)$ & $\mathrm{p}=0.030$ \\
Positive & $9.68 \%(7)$ & $77.42 \%(57)$ & $12.90 \%(9)$ &
\end{tabular}

*Fisher's Test.

Table 7. Ki-67 expression according to the diagnosis of mammary neoplasms in bitches

\begin{tabular}{cccc}
\hline & Benign & Carcinoma & $\mathrm{P}$ value $^{\mathrm{a}}$ \\
\hline Negative & $63.33 \%(46)$ & $36.67 \%(27)$ & $\mathrm{p}=0.016$ \\
Positive & $30.77 \%(22)$ & $69.23 \%(51)$ & \\
\hline
\end{tabular}

aFisher's Test.

Table 8. Ulceration according to PCNA expression

\begin{tabular}{cccc}
\hline & No & Yes & $\mathrm{P}$ value \\
\hline Mild & $87.50 \%(64)$ & $12.50 \%(9)$ & \\
Intense & $61.40 \%(45)$ & $38.60 \%(28)$ & $\mathrm{p}=0.035$ \\
Negative & - & $100.00 \%(73)$ & \\
\hline
\end{tabular}

aFisher's Test.
Table 9. Lymphocyte infiltration according to PCNA and Ki-67 expression

\begin{tabular}{lcccc}
\hline & None & Mild & $\begin{array}{c}\text { Moderate }+ \\
\text { intense }\end{array}$ & P value \\
\hline PCNA & & & \\
Negative & $87.50 \%(64)$ & $12.50 \%(43)$ & - & $\mathrm{p}=0.02$ \\
Positive & $58.93 \%(9)$ & $30.36 \%(22)$ & $10.71 \%(8)$ & \\
Ki-67 & & & & \\
Negative & $64.41 \%(47)$ & $30.51 \%(22)$ & $5.08 \%(4)$ & $\mathrm{p}=0.034$ \\
Positive & $69.23 \%(50)$ & $7.69 \%(6)$ & $23.08 \%(17)$ &
\end{tabular}

positive cells) in $21 \%,++++(>75 \%$ of positive cells) in $8 \%$ and $16 \%$ of the fragments were considered negative for this marker (Fig.1A).

The statistical analysis of E-cadherin showed there was no significant correlation among its expression and metastasis, survival or disease-free interval. However, the Nominal Logistic Regression showed an association of low E-cadherin expression and the diagnosis of carcinoma $(p=0.032)$ (Table 4). Fisher's test showed an association between the loss of E-cadherin expression, abnormal body status (obesity or cachexia) $(p=0.030)$ and pseudopregnancy $(p=0,021)$ (Table 5 and 6$)$.

Ki-67 expression was nuclear and it was less intensive than PCNA expression. Ki-67 expression was + (focal) in $48 \%$ of the cases; $++(25-50 \%$ of positive cells) in $27 \%$; $+++(50-75 \%$ of positive cells $)$ in $14 \%,++++(>75 \%$ of positive cells) in $5 \%$ and $6 \%$ of the fragments were considered negative for this marker (Fig.1B). PCNA expression was nuclear and was intense in most slides. It was + (focal) in $10 \%$ of the cases; ++ (25-50\% of positive cells) in $20 \%$; +++ $(50-75 \%$ of positive cells) in $30 \%,++++$ (>75\% of positive cells) in $40 \%$ and there were no negative fragments for this marker (Fig.1C).

Nominal Logistic Regression indicated a greater likelihood of carcinoma with positive Ki-67 ( $p=0.016)$, considering carcinoma as the most malignant of the tumors (Table 7). There was no association between PCNA and the diagnosis but there was an association between PCNA and ulceration $(p=0.035)$ and body status, taking into consideration cachexia and obesity $(p=0.030)$ (Table 8$)$. Fisher's test also indicated a greater likelihood of lymphocyte infiltration $(p=0.02)$ when compared to Ki-67 and to PCNA ( $p=0.034)$ (Table 9).

\section{DISCUSSION}

The analyzed clinical data, reproductive history and hormonal status did not show a significant statistical relationship with the diagnosis, prognosis or survival time. Female undefinid breed dogs (UB), Teckels and Poodles, ages ranging from 5 to 10 years had a greater incidence of tumors. These data are similar to those of a study carried out by Rutteman et al (2000) who report the presence of mammary neoplasm in female dogs with mean age of 10 years and rarely with less than 4 years of age and the most affected breeds are Poodle, German Shepherd, 

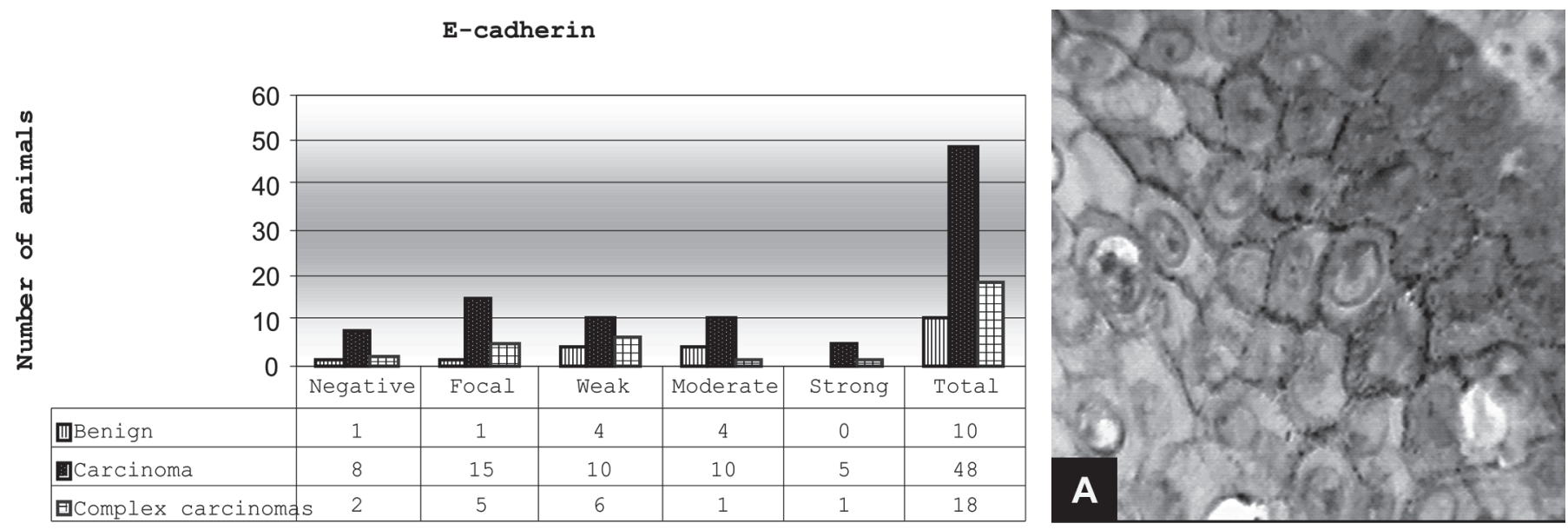

Ki-67
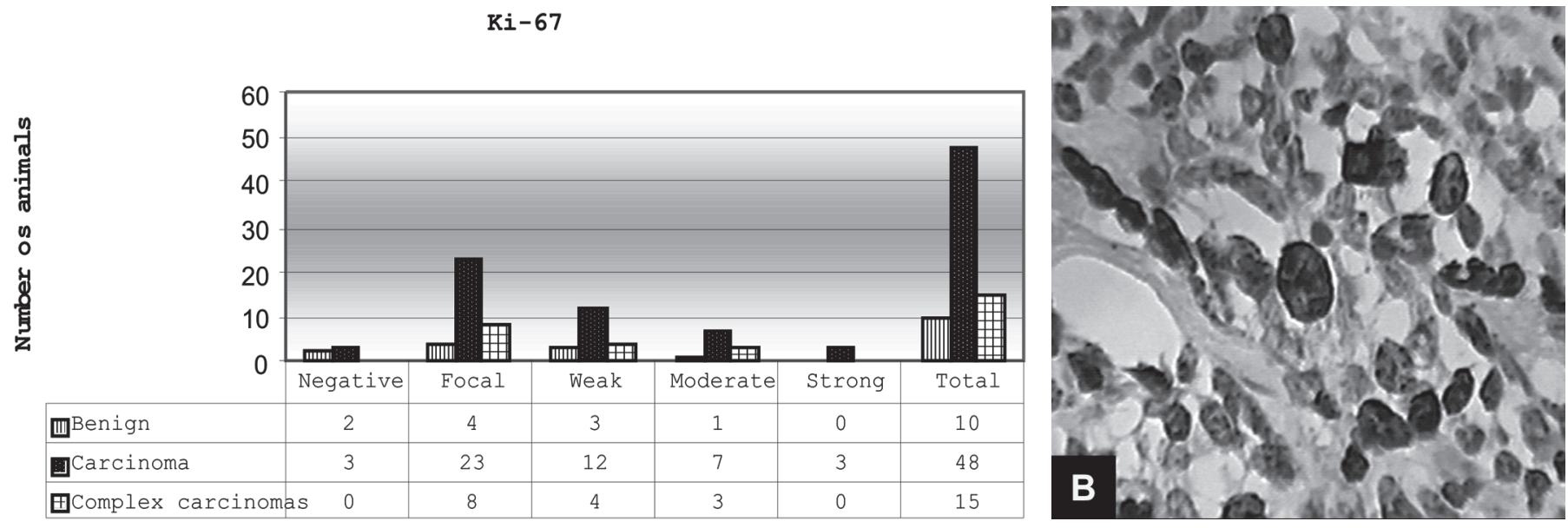

PCNA
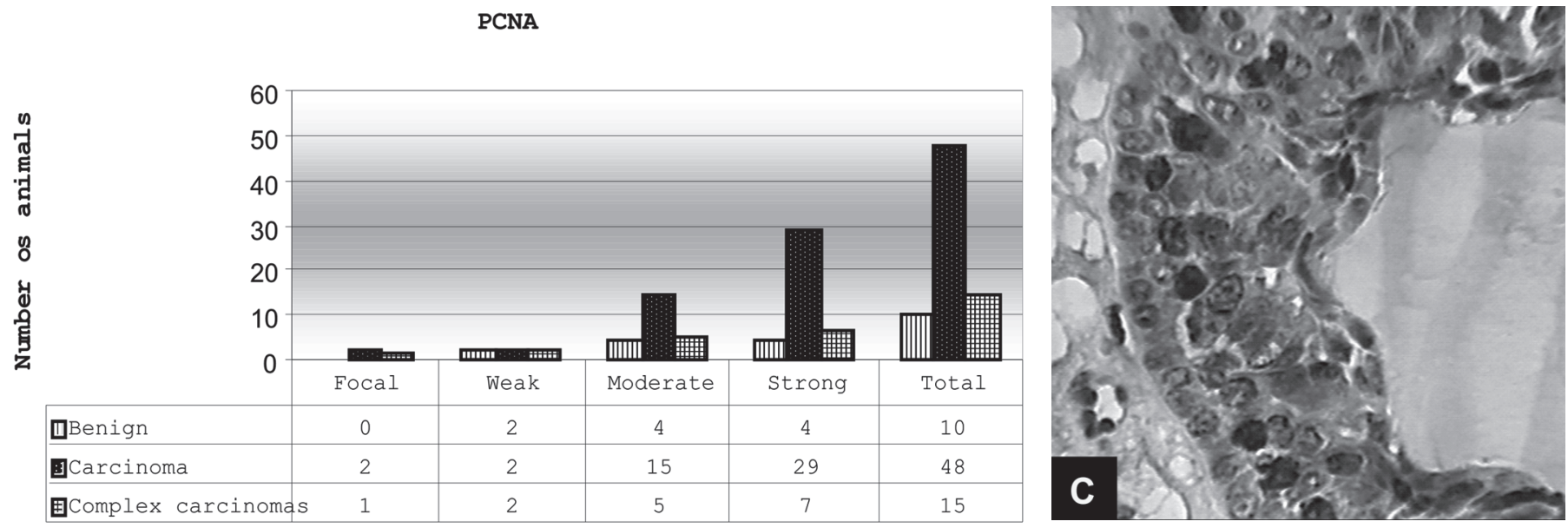

Fig.1. Scheme showing the antibody expression and its photomicrography in canine mammary neoplasm: (A) E-cadherin, 100x; (B) Ki-67, 40x; (C) PCNA, 40x.

Cocker Spaniel, in addition to undefined breed animals. Feeding with homemade food did not have a statistical correlation with any of the investigated items, but it demonstrates a population trend, which is not used to feed chow to pets and does not confirm the studies carried out by Sørenmo (1998), who observed a greater incidence of mammary neoplasm in female dogs fed on homemade food.
The histopathological diagnosis showed that malignant tumors were the most prevalent with $86 \%$ of the cases and $60 \%$ of the tumors were greater or equal to $5 \mathrm{~cm}$, with an evolution time greater than 6 months, indicating that owners were delayed in searching for veterinarian care. The outcome analysis and the analysis of the histopathological records of the tumors allowed the confirmation of the malignancy of these neoplasms. Furthermore, the 
correlation of histopathological diagnosis, histological grade and the presence of necrosis in the tumor fragments were confirmed.

High e-cadherin expression, which is considered a likely marker of favorable prognosis in the literature, showed a good expression in this sample. There was a statistical association between the low expression of $\mathrm{E}$-cadherin with carcinomas. High E-cadherin expression indicates that the cell adhesion is preserved, and thus, the risk of distant metastasis is considerably low, since the possibility of neoplastic cells reaching the circulatory flow is virtually none. Taking into consideration that the lack of expression of this marker is related to lower cellular adhesion, which increases the likelihood of distant metastasis, these results confirm the relationship of low e-cadherin expression and a bad prognosis. These results are in accordance with literature data (Bruno \& Darzynkiewicz 1992, Heimann et al. 2000, Pedersen et al. 2002), since $86 \%$ of the groups' neoplasms were malignant, which explains the low Ecadherin expression (only $8 \%$ of the fragments showed staining in over $50 \%$ of the cells). There was an association between body status (cachexia and obesity) and pseudopregnancy with low E-cadherin expression and therefore, these clinical parameters may be considered as risk factors.

In addition, the period of 18 months post-surgery was confirmed as having a greater chance of developing metastasis.

High Ki-67 and PCNA expression are considered as likely markers of unfavorable prognosis in the literature, and both markers showed a good expression in this sample. Nuclear staining was preponderant for the Ki-67 antibody. There was a positive expression of $\mathrm{Ki}-67$ in the whole study group, however, with different intensities. A large part of the malignant tumors $(63 \%)$ had a high expression of this marker whereas a low expression was observed in the benign tumors.

Zuccari (2001) reports Ki-67 as an excellent marker of cell proliferation in the diagnosis and prognosis of mammary carcinomas and for malignancy in mammary tumors in canines. Thus, Ki-67 specific antibodies provide immunohistochemical access to cell proliferation, allowing the assessment of cell growth and are useful to establish the prognosis in human neoplasms (Bouzubar et al. 1989). Ki-67 has been reported as a superior marker of cell proliferation, since it influenced by internal and external factors such as the PCNA. Moreover, its nuclear expression during the cell cycle, as opposed to the PCNA, may represent an advantage when compared to the use of PCNA as a biological marker (Gerdes et al. 1992).

More recently, other authors have tried to relate cell proliferation markers with the diagnosis, prognosis and outcome of breast neoplasms (Pena et al. 1998, Zacchetti et al. 2003, Kushlinskii et al. 2004, Zuccari et al. 2004, Nowak et al. 2006). Nowak et al. (2006) confirmed the relationship between Ki-67 and PCNA. Peña et al. (1998) reported the prognostic relationship of $\mathrm{Ki}-67$ with metastasis, disease-free interval and survival, and thus considered it as having a prognostic value. For the same authors, malignant tumors and PCNA had a positive correlation with the histological and nuclear grade of mammary tumors in canines.

Statistical analysis showed an association of carcinomas with marked Ki-67 expression. This result confirms literature data reporting $\mathrm{Ki}-67$ as a marker for carcinomas and a marker of unfavorable prognosis (Zuccari et al. 2004). PCNA increases after the G1 phase of the cell cycle, reaching a maximum peak in the $S$ phase and decreasing after $\mathrm{G} 2$, and then presents very low levels in the M phase and in quiescent cells which are not detected by immunohistochemical methods (Tsuji et al. 1992, Huang et al. 1994, Rabenhorst et al. 1994, Martinez-Lara et al. 1996). The lack of PCNA in DNA replication reactions results in the accumulation of primers and even in cellular quiescence. The gene that codifies PCNA has been cloned in different species and although there are minor differences in DNA, there is a considerable similarity between the human PCNA and the PCNA of other species (McMormick \& Hall 1992). According to Mighell (1995), the PCNA cannot be considered a good marker of cellular proliferation, since PCNA levels may remain high when induced by growth factors resulting from DNA damage. Other factors may also play a role, such as the type of fixation agent, fixation time, status of the specimen, the fact that the PCNA has a rather long half-life, indicating that the cell nucleus may remain PCNA positive even after stimulation.

PCNA demonstrated intensive nuclear staining in the studied slides. There was a statistical trend of association between this marker and malignant tumors, which was not confirmed due to the small number of benign tumors in the study group. Moreover, PCNA, as previously described, has a long cellular half-life and may be expressed in the phases of cellular repair, making it difficult to evaluate it as a marker of cellular proliferation. There are no literature data relating this marker to the body status of animals with neoplasm.

Lymphocyte infiltration had a positive relationship with both markers and if we consider it as an unfavorable prognostic factor, it may be used as a prognosis indicator.

The relationship between PCNA and ulceration was also observed. If we taking into consideration that ulceration results from the rapid tumor growth which does not obtain adequate blood supply thus leading to necrosis, this proliferation marker could confirm it. In addition, increased PCNA expression was observed in animals with abnormal body status, such as cachexia, obesity, which are easy to evaluate and when combined may assist in defining the prognosis of the animal.

Our results show that the use of these antibodies combined to others which may establish a panel of markers, might contribute for a more accurate tumor prognosis, leaving aside a complex and inconclusive classification as a single alternative in the pursuit for a 
better and longer survival of cancer patients. Furthermore, the limited number of studies in Veterinary Medicine, investigating new prognosis and predictive markers for mammary neoplasm is a promising investigation field. The immunohistochemical diagnosis of tumors by markers combined with clinical-pathological parameters allow a better assessment of the prognosis, leading to a better clinical outcome of the patient.

\section{CONCLUSIONS}

Clinical data, reproductive history and hormonal status, as well as microscopic and macroscopic characteristics of tumors, as possible prognosis factors did not present significant results when related to the diagnosis, prognosis or survival time of patients with breast neoplasm.

There was a significant relationship between survival time in female dogs and malignancy, observed in the histopathological tests of the tumors. The period with a higher incidence of metastasis and recurrence of up to 18 postoperative months was also confirmed.

The low expression of e-cadherin in carcinomas was confirmed, and therefore it may be considered as a marker of favorable prognosis.

Changes in body status, such as cachexia and obesity in patients with mammary neoplasm may be considered unfavorable prognosis factors when associated to low ecadherin expression and high PCNA expression.

Pseudopregnancy has a significant correlation with low e-cadherin expression and may be considered an independent prognosis factor.

There was a significant relationship between survival time in female dogs and malignancy, observed in the histopathological tests of the tumors.

The superiority of Ki-67 as a cell proliferation marker was confirmed and it was considered an unfavorable prognosis marker when associated to carcinomas.

The presence of lymphocyte infiltration in the histopathological examination of the tumors may be considered an unfavorable prognosis factor when associated to proliferation markers.

The presence of ulceration, a macroscopic and easily observed characteristic of tumors, may be considered and unfavorable prognosis factor when associated to marked PCNA expression.

Acknowledgments.- To Prof. Dr. Felipe Augusto Ruiz Sueiro for his support in reading and analyzing the slides, and to Prof. Dr. José Antônio Cordeiro for the statistical analysis of study data. To FAPESP for funding this project (Proc.02/05336-2).

\section{REFERENCES}

Allred C.D., Harvey J.M., Berardo M. \& Clark G.M. 1998. Prognostic and predictive factors in breast cancer by immunohistochemical analysis. Modern Pathol. 11(2):155-168.

Asgeirsson K.S., Jonasson J.G., Tryggvadorttir L., Olafsdottir K., Sigurgeirsdottir J.R., Ingvarsson S. \& Ogmundsdottir H.M. 2000. Altered expression of E-cadherin in breast cancer: patterns, mechanisms and clinical significance. Eur. J. Cancer 36:1098-1106.
Berx G. \& Roy F.V. 2001. The E-cadherin/catenin complex: an important gatekeeper in breast cancer tumorigenes and malignant progression. Breast Cancer Res. 3:289-293.

Bouzubar N., Walker K.J., Griffiths K., Ellis I.O., Elston C.W., Robertson J.F., Blamey R.W. \& Nicholson R.I. 1989. Ki67 immunostaining in primary breast cancer: pathological and clinical associations. Brit. J. Cancer 59(6):943-947.

Bravo R., Frank R., Blundell P.A. \& MacDonald-Bravo H. 1987. Cyclin/ PCNA is the auxiliary proyein of polimerase-d. Nature 326(6112):515517.

Brunetti B., Sarli G., Preziosi R., Monari I. \& Benazzi C. 2005. E-cadherin and $\beta$-catenin reduction influence invasion but not proliferation and survival in canine malignant mammary tumors. Vet. Pathol. 42:781787.

Bruno S. \& Darzynkiewicz Z. 1992. Cell cycle dependent expression and stability of the nuclear protein detected by Ki-67 antibody in HL60 cell. Cell Prolif. 25(1):31-40

Charpin C., Garcia S., Bouvier C., Devictor B., Andrac L., Choux R. \& Lavaut M. 1997. E-cadherin quantitative immunocytochemical assays in breast carcinomas. J. Pathol. 181:294-300.

Delahunt B., Betwaite P.B., Thornton A. \& Ribas J.L. 1995. Proliferation of renal cell carcinoma assessed by fixation-resistant polyclonal Ki-67 antibody labeling: correlation with clinical outcome. Cancer 75:27142719.

Fitzgibbons P.L., Page D.L., Weaver D., Thor A.D., Allred C., Clark G.M., Ruby S.G., O'Malley F., Simpson J.F., Connolly J.L., Hayes D.F., Edge S.B., Lichter A. \& Schnitt S.J. 2000. Prognostic factors in breast cancer. College of American Pathologists Consensus Statement 1999. Arch. Pathol. Laborat. Med. 124:966-978.

Gamallo C., Palacios J., Suarez A., Pizarro A., Navarro P., Quintanilla M. \& Cano A. 1993. Correlation of E-cadherin expression with differentiation grade and histological type in breast carcinoma. Am. J. Pathol. 142:987-993.

Gasparini G., Boracchi P., Verderio P. \& Bevilacqua P. 1994. Cell kinetics in human breast cancer: comparison between the prognostic value of the cytofluorimetric S-phase fraction and that of the antibodies to Ki67 and PCNA antigens detected by immunocytochemistry. St Bortolo Medical Centre, Vicenza, Italy.

Gerdes J., Lemke H., Baisch H., Wacker H.H., Schwab U. \& Stein H. 1984. Cell cycle analysis of a cell proliferation associated human nuclear antigen defined by the monoclonal antibody Ki-67. J. Immunol. 133:1710-1715.

Gerdes J., Becker M.H.G. \& Key G. 1992. Immunohistological detection of tumor growth fraction (Ki-67 antigen) in formalin fixed and routinely tissues. J. Pathol. 168(1):85-87.

Gillett C.E., Miles D.W., Ryder K., Skilton D., Liebman R.D., Springall R.J., Barnes D.M. \& Hanby A.M. 2001. Retention of the expression of $\mathrm{E}$-cadherin and catenins is associated with shorter survival in grade III ductal carcinoma of the breast. J. Pathol. 193:433-441.

Glukchova M., Koteliansky V. \& Sastre X. 1995. Adhesion systems in normal breast and in invasive breast carcinoma. Am. J. Pathol. 146:706-716.

Guriec N., Marcellin L., Gairard B., Caldéroli H., Wilk A., Renaud R., Bergerat J.P. \& Oberling F. 1996. E-cadherin mRNA expression in breast carcinomas correlates with overall and disease-free survival. Invasion and Metastasis 16:19-26.

Heimann T., Lan F.S., McBride R. \& Hellman S. 2000. Separating favorable from unfavorable prognostic markers in breast cancer: the role of E-cadherin. Cancer Res. 60:298-304.

Huang W.Y., Coltrera M., Schubert M., Morton T. \& Truelove E. 1994. Histopathologic evaluation of proliferating cell nuclear antigen (PC10) in oral epithelial hyperplasias and premalignat lesions. Oral Surg. Oral Med. Oral Pathol. Oral Radiol. Endod. 78(6):748-754.

Kovacs A., Dhillon J. \& Walker R.A. 2003. Expression of P-cadherin, 
but not E-cadherin or $\mathrm{N}$-cadherin, relates to pathological and functional differentiation of breast carcinomas. Molecular Pathol. 56:318-322.

Kowalsky P.J., Rubin M.A. \& Kleer C.G. 2003. E-cadherin expression in primary carcinomas of the breast and its distant metastases. Breast Cancer Res. 5:217-222.

Kushlinskii N.E., Orinovskii M.B., Gurevich L.E., Kazantseva I.A., Talaeva ShZh, Ermilova V.D., Dvorova E.K., Ozherel'ev A.S. \& Letiagin V.P. 2004. The specificity of expression of molecular biological markers in tumors of the mammary gland. Vestn. Ross Akad. Med. Nauk. 5:3236.

Lipponen P., Saaelainen E., Ji H., Aaltomaa S. \& Syrjanen K. 1994. Expression of E-cadherin is related to other prognostic factors and survival in breast cancer. J. Pathol. 174:101-109.

MacEwen E.G. 1990. Spontaneous tumors in dogs and cats: Models for the study of cancer biology and treatment. Cancer and Metastases Review 9(1):125-136.

Martinez-Lara I., Gonzáles-Moles M.A., Ruiz-Avila I., Bravo M., Ramos M.C. \& Fernández-Martinez J.A. 1996. Proliferating cell nuclear antigen (PCNA) as a marker of dysplasia in oral mucosa. Acta Stomatol. Belg. 93(1):29-32.

Matos A.J.F., Lopes C., Carvalheira J., Santos M., Rutteman G.R. \& Gartner F. 2006. E-cadherin expression in canine malignant mammary tumours: relationship to other clinico-pathological variables. J. Comp. Pathol. 134:182-189.

McMormick D. \& Hall P.A. 1992. The complexities of proliferating cell nuclear antigen. Histopathology 21(6):591-594.

Mighell A. 1995. PCNA and p53. Eur. J. Cancer B, Oral Oncology 31(6):403-404.

Misdorp W. 2002. Tumors of the mammary gland, p.575-606. In: Meulten D.J. (ed.), Tumors in Domestic Animals. 4th ed. lowa State Press, Ames.

Nowak M., Madej J.A., Dziegiel P. \& Kanzawa H. 2006. Immunohistochemical identification method of tumour cells in the $S$ phase of mitotic cycle and its usefulness in diagnostics of mammary gland adenocarcinomas in bitches. Pol. J. Vet. Sci. 9(1):57-62.

Oesterreich S., Deng W., Jiang S., Cui X., Inanova M., Schiff R., Kaiyan K., Kang K., Hadsell D.L., Behrens J. \& Lee A.V. 2003. Estrogenmediated down-regulation of E-cadherin in breast câncer cells. Cancer Res. 63:5203-5208.

Oyama T., Mitsudomi T., Mizone T., Ohgami T., Nakanishi R. \& Yasumoto K. 1995. Proliferating cell nuclear antigen may be superior to argyrophilic nucleolar organizer regions in predicting shortened survival of patients with non-small cell lung cancer. Surg. Oncol. 4:83-89.

Pedersen K.B., Nesland J.M. \& Maelandsmo G.M. 2002. Expression of S100A4, E-cadherin, $\alpha$-and $\beta$ - catenin in breast cancer biopsies. Brit. J. Cancer 87:1281-1286.

Pena L.L., Nieto A.I., Perez-Alenza D., Cuesta P. \& Castano M. 1998. Immunohistochemical detection of Ki-67 and PCNA in canine mammary tumors: relationship to clinical and pathologic variables. J. Vet. Diagn. Invest. 10(3):237-246.

Perez A.M.D.M., Peña L., Del Castilho N. \& Nieto A.L. 2000. Factors influencing the incidence and prognosis of canine mammary tumours. Small Anim. Pract. 41(10):476.

Pignatelli M., Liu D. \& Nasim M. 1992. Morphoregulatory activities of Ecadherin and beta-1 integrins in colorectal tumourcells. Brit. J. Cancer 66:629-634.

Pignatelli M. 1993. E-cadherin: a biological marker of tumor differentiation. J. Pathol. 171:81-82.

Queiroz L.M.G. 1997. Expressão do PCNA, Ki-67, cerbB-2 e p53 no carcinoma adenóide cístico e adenocarcinoma polimórfico de baixo grau de malignidade de glândula salivar menor. São Paulo. 78p. Tese de Doutorado em Patologia Bucal, Faculdade de Odontologia, Universidade de São Paulo.
Rabenhorst S.H., Burini R.C. \& Schmitt F.C.L. 1993. Marcadores de proliferação celular. Revta Bras. Patol. Clín. 29(1):24-29.

Rabenhorst S., Burini R. \& Schmitt F. 1994. Ciclo celular: mecanismos reguladores e marcadores bioquímicos. Revta Bras. Cancerologia 40:141-147.

Reis-Filho J.S., Paredes J., Milanezi F. \& Schmitt F.C. 2002. Clinicopathological implications of E-cadherin reactivity in patients with lobular carcinoma in situ of the breast. Cancer 94:2114-2115.

Reis A.L., Carvalheira J., Schmitt F.C. \& Gärtner F. 2003. Immunohistochemical study of the expression of E-cadherin in canine mammary tumours. Vet. Rec. 152:621-624.

Restucci B., Papparella S., De Vico G. \& Maiolino P. 1997. E-cadherin expression in normal and neoplastic canine mammary gland. J. Comp. Pathol. 116:191-202.

Rutteman G.R., Withrow S.J. \& MacEwen E.G. 2001. Tumors of the mammary gland, p.455-477. In: Withrow S.J. \& MacEwen E.G.W.B. (ed.), Small Animal Clinical Oncology. 3rd ed. W.B. Saunders, Philadelphia.

Sanchez Y. \& Elledge S.J. 1995. Stopped for repairs. Bioessays 17:545548.

Siitonen S.M., Kononen J.T., Helin H.J., Rantala I.S. \& Isola J.J. 1996. Reduced E-cadherin expression is associated with invasiveness and unfavourable prognosis in breast cancer. Am. J. Clin. Pathol. 105:394402.

Sørenmo K. 1998. An update on canine mammary gland tumors. Proc. $16^{\text {th }}$ Acvim Forum, p.387-388.

Tahan S.R., Neuberg D.S., Dieffenbach A. \& Yacoub L. 1993. Prediction of Early Relapse and Shortened Survival in Patients with Breast Cancer by Proliferating Cell Nuclear Antigen Score. Department of Pathology, New England Deaconess Hospital, Boston, MA 02215.

Takeishi M. 1991. Cadherin cell adhesion receptors as a morphogenetic regulator. Science 251:1451-1455.

Thomas M., Noguchi M., Kitagawa H., Kinoshita K. \& Miyazaki I. 1993. Poor Prognostic Value of Proliferating Cell Nuclear Antigen Labelling Index in Breast Carcinoma. Second Department of Surgery, Kanazawa University Hospital, Japan.

Thomas E. \& Berner G. 2000. Prognostic and predictive implications of HER2 status for breast cancer patients. Eur. J. Oncology Nursing 4:1017. Disponível em: <http//www.idealibrary.com.br>. Acesso em: 8 jan. 2001

Tsuji T., Shrestha P., Yamada K., Shinozaki F., Sasaki K., Maeda K. \& Mori M. 1992. Proliferating cell nuclear antigen in malignant and premalignant lesions of epithelial origin in the oral cavity and skin: an immunohistochemical study. Virchows Archiv A, Pathol. Anat. 420:377383.

Van T., Veer L.J., Dai H., Van de Vijver M.J., He Y.D., Hart A.A., Mao M., Peterse H.L., Van der Kooy K., Marton M.J., Witteveen A.T., Schreiber G.J., Kerkhoven R.M., Roberts C., Linsley P.S., Bernards R. \& Friend S.H. 2002. Gene expression profiling predicts clinical outcome of breast cancer. Nature 415:530-536.

Veronese S.M., Gambacorta M., Gottardi O., Scanzi F., Ferrari M. \& Lampertico P. 1993. Proliferation Index as a Prognostic Marker in Breast Cancer. Department of Pathology, Niguarda, Ca, Granda Hospital, Milan, Italy.

WHO (World Health Organization). Histological Classification of Tumors of Domestic Animals by the Armed Forces Institute of Pathology AFIP. Disponível em <http://www.afip.org/vetpath/who/whomamm.htm>. Acesso em: 05 jul. 2007.

Wintzer H.O., Zipfel I., Schulte-Mönting J., Hellerich U. \& Von Kleist S. 1991. Ki-67 immunostaining in Human Breast Tumors and its Relationship to Prognosis. Institute of Immunobiology, University of Freiburg, Federal Republic of Germany.

Zacchetti A., Van Garderen E., Teske E., Nederbragt H., Dierendonck J.H. \& Rutteman G.R. 2003. Validation of the use of proliferation 
markers in canine neoplastic and non-neoplastic tissues: comparison of $\mathrm{KI}-67$ and proliferating cell nuclear antigen (PCNA) expression versus in vivo bromodeoxyuridine labelling by immunohistochemistry. APMIS 111(3):430-438.

Zschiesche W., Schonborn I., Behrens J., Herrenknecht K., Hartveit F., Lilleng P. \& Birchmeier W. 1997. Expression of E-cadherin and catenins in invasive mammary carcinomas. Anticancer Res. 17:561-568.
Zuccari D.A.P.C. 2001. Estudo imunocitoquímico de marcadores diagnósticos e prognósticos em neoplasias mamárias caninas. Tese de Doutorado em Clínica Médica Veterinária, Faculdade de Ciências Agrárias e Veterinárias, Unesp-Jaboticabal, SP. 92p.

Zuccari D.A.P.C., Santana A.E., Cury P.M., Cordeiro J.A. \& Zancheta D. 2004. Immunocytochemical study of Ki-67, as a prognostic marker in canine mammary neoplasias. Vet. Clin. Pathol. 33(1):23-28. 